\title{
Rescaling migration studies: migration policy making and implementation at the local government level
}

How 'the state' perceives and responds to migration is gaining increasing attention. This analysis seeks to encourage debate on scales of governance in migration studies through a focus on policy making and implementation on the part of local government officials in Scotland. Contributions include the elucidation of how immigrants are differentiated by individual local state actors and how this relates to the wider practices of local government towards them, and a typology conceptualising the heterogeneity of local state responses to immigration. This analytic emphasis on local state perceptions of, and responses to, migration and migrants hopes to inspire more nuanced and policy relevant understandings of 'the state' in migration research. Keywords: local government, migration, policy, scale, Scotland, the state

Authors;

David McCollum* and Helen Packwood, University of St Andrews, Fife, Scotland, KY16 9AL

*Corresponding author

\section{David.McCollum@st-andrews.ac.uk}

01334463903

Acknowledgement

This research was conducted by researchers in the Centre for Population Centre, which is funded by the Economic and Social Research Council (ESRC) grant number RES-625-280001. The authors wish to thank Allan Findlay for his comments on earlier drafts of this paper. 


\section{Rescaling migration studies: migration policy making and implementation at the local government level}

How 'the state' perceives and responds to migration is gaining increasing attention. This analysis seeks to encourage debate on scales of governance in migration studies through a focus on policy making and implementation on the part of local government officials in Scotland. Contributions include the elucidation of how immigrants are differentiated by individual local state actors and how this relates to the wider practices of local government towards them, and a typology conceptualising the heterogeneity of local state responses to immigration. This analytic emphasis on local state perceptions of, and responses to, migration and migrants hopes to inspire more nuanced and policy relevant understandings of 'the state' in migration research.

Keywords: local government, migration, policy, scale, Scotland, the state

\section{Migration and scales of governance: the local}

The focus of this paper is the perceptions and practices of local government officials with regards to the reception and integration of recent migrants. This is an issue which occupies a neglected position within discussions concerning scales of governance in migration studies, where the sub-national scale has been relatively neglected in comparison to analyses at the national and supranational levels (Leitner et al, 2002). An accusation long levied at migration scholarship is that the state is often framed as a monolithic and dispassionate institution whose primary function in the migration system is the regulation of international population flows (Massey, 1999). Migration scholarship has responded to these criticisms by paying greater attention to the issue of migrant policy making and implementation at the regional and local scales. For example a growing body of evidence is charting how states and provinces are 
increasingly drafting legislation aimed at immigration controls in the USA and Canada respectably (Varsanyi, 2010; Paquet, 2014; Bohn et al, 2013). Nonetheless how policy is developed and implemented 'on the ground' at the local government level remains a relatively neglected area of study (Rodriguez, 2008), meaning that accounts of these processes often fail to acknowledge the obvious point that governance is constituted at and operates across a range of spatial scales (Brenner, 2004).

Research at this scale is of practical as well as conceptual relevance. Although national government legislates on the quantities and qualities of migrants that can legally enter a country, it is ultimately local government that is responsible for providing services to immigrant communities and ensuring that they successfully integrate into their new surroundings. As Alexander $(2007,6)$ pointedly observes 'ultimately national level policies are tried, tested and articulated at the local level, in the school and in the neighbourhood, here local authority actions (or inactions) remain significant'. In the UK and many other nations which have experienced relatively large migrant inflows over the past few decades, national government has been surprisingly non-prescriptive in terms of specifying how local government should react to new arrivals from overseas (Saggar and Somerville, 2012). As such, not only are local authority areas distinct in terms of their experiences of immigration (Poppleton et al, 2013), but local governments perceive immigration and respond to immigrants in a strikingly diverse range of ways (Alexander, 2003). The focus of this paper is research amongst local government officials concerning their representations of immigration. A typology of local authorities is constructed from our field research, providing a better understanding of perceptions and practices at this scale of migration governance. In the final section we reflect on the significance of the state at the scale of the local in the implementation of immigration policy, discuss what this means for how scales of governance are theorised in 
migration studies and consider the wider question of the extent to which academic work in the social sciences should aim for 'policy relevance'.

\section{Local government and migration: conceptual framework}

This research is inspired by three distinct analytical approaches. First is Alexander's (2003; 2007) consideration of urban European local authority responses to the 'strangers in their midst'. Second is Jones's $(2013 ;$ 2014) work involving the perceptions and responses of policy practitioners in local authorities in England to migration integration. Thirdly the research draws on the nascent literature in the US on local bureaucratic incorporation, the process whereby local bureaucracies proactively develop responses to migration within the constraints of national level policies (Marrow, 2009; Lewis and Ramakrishnan, 2007; Gleeson and Gonzales, 2011). These perspectives are part of a wider recasting of conventional understandings of the role and sovereignty of the nation-state in migration research (Hollifield, 2004), with a gradual shift away from this unit of analysis being perceived and presented as a single unitary, indivisible and internally coherent institution which enacts policy predominantly at the national scale (Favell, 2001). Wider debates concerning the so-called 'rescaling' of the state centre on the extent to which its operations at multiple spatial scales is being potentially transfigured from 'above' and 'below' by transfers of powers and resources to supranational and subnational tiers of government (Lobao et al, 2009). These ideas are particularly pertinent to this investigation, where local government officials in Scotland must simultaneously operate within the legislative framework of policies developed at two 'national' scales (Scottish and UK governments) and at the supranational level (European Union, at least until the UKs expected withdrawal in 2019). 
The relative neglect of the local scale of governance in migration studies is problematic because it is at this level that national and even supranational legislation is ultimately implemented and experienced. Local rather than national governments are usually held responsible for integrating and providing services to immigrants, and despite unprecedented increases in the scale and diversity of immigration since the late 1990s Britain and many other European countries do not have official integration programmes (Saggar and Somerville, 2012). In the context of migration, these processes have been conceptualised as involving a strategic reinvention and rescaling of decision making on the part of central governments 'upward' to intergovernmental bodies, 'downward' to regional and local authorities and 'outward' to nonstate actors (Guiraudon and Lahav, 2000; Samers, 2001).

This analysis focuses on a specific aspect of these processes, that of the downward rescaling of responsibility for immigration from national to local government. This is not a novel phenomenon (Rodriguez, 2008), but the body of evidence relating to local government perceptions of and responses to migration remains underdeveloped, with most of the research on these issues taking a practical rather than theoretical focus (e.g. Audit Commission, 2007; Byrne and Tankard, 2007; Saggar and Somerville, 2012). The prominence of government, think tank and research consultancy literature in this area relates to a tangential but nonetheless significant issue: the policy relevance and political function of academic research in migration studies and the social sciences more generally (Boswell, 2009). There is widespread acceptance of the merit of policy relevant migration research (Iredale et al, 2004; Laczko and Wijkström, 2004), although see Bakewell (2008) for an opposing view. However academic research can often be too abstract or irrelevant to inform policy issues and public opinion, and communication between academics and policymakers is often non-existent or ineffective (Boswell, 2009). This can be at least partly attributed to the incentives within academia 
favouring publication in peer reviewed journals and other forms of dissemination within academic circles, which are often inaccessible to policymakers and fail to keep pace with fast moving policy agendas (Laczko and Wijkstrom, 2004). Institutional pressures that result in competing priorities between researchers and policymakers thus represent an important aspect of wider discussions regarding how 'impact' can be achieved through social research, how political uses of expert knowledge can be promoted, and indeed the extent to which these should be considered fundamental goals of the academy. We offer some further reflections on the thorny issue of 'policy relevant research' at the conclusion of this paper.

A notable exception to absence of the local scale in migration governance research discussed above is the relatively established literature that emphasises the contradictions and tensions between spatial scales of migration governance in the federal government systems of the United States and Canada (Zolberg, 2006; Klebaner, 1958). This evidence base has grown in recent years, largely prompted by the increasing prevalence of state and local initiatives aimed at immigration control (Varsanyi, 2010; Paquet, 2014; Bohn et al, 2013). However these investigations have tended to consider policy outcomes, in terms of issues such (irregular) migrant behaviour and settlement patterns, rather than the processes through which they are developed and implemented by officials at the local level.

In stark contrast to the North American context, conceptualisation of sub-national policymaking and implementation is much rarer in the European context, where the centralised governmental systems of most countries means that national governments have retained greater control over the regulation of immigration, as well as transferring some of this authority 'upwards' to the European Union level (Gerber and Kollman, 2004). Against this backdrop the 
contribution of Alexander (2003) represents a rare example of theorising local government responses to migration in Europe. Drawing on a literature review of policy reactions to the settlement of migrants in 25 European cities dating back to the 1960s, an analytical framework involving 'host-stranger relations' is developed to reveal and classify the wide diversity of attitudes and responses to immigration that exist at the local policy level. Local governments and individual officials, Alexander notes, often hold and exercise a significant degree of autonomy in terms of how they portray and respond to immigration. This analysis is also sensitive to the range of ways in which migration is experienced and responded to by individuals and institutions at the local government scale (Table 1).

Returning to the North American context, Alexander's (2003) findings are echoed in recent research into the concept of local migrant bureaucratic incorporation (Marrow, 2009; Lewis and Ramakrishnan, 2007; Gleeson and Gonzales, 2011). This research focuses on the complexities of how local public servants such as teachers and police officers interpret and apply national legislation. Largely drawing on in-depth qualitative research involving local state actors, these perspectives have highlighted a remarkable degree of autonomy and variety in terms of how local bureaucracies, operating within a wider national legislative framework, develop their own practices towards immigration control and migrant integration. As noted by de Graauw (2015), responsiveness to immigrants as rationalised by factors internal to local bureaucracies can explain how officials assist migrants in ways that do not sit within or that even directly contradict national immigration control regulations. However de Graauw (2015) also contends that the bureaucratic incorporation approach underplays the role that factors that are external to local governments act to shape their responses to migration. The analytical focus of this paper attempts to account for how both internal and external factors shape migration policy making and implementation at the local scale in Scotland. 
The approach taken in this research also draws inspiration from Jones's $(2013 ; 2014)$ insightful depiction of how issues relating to migration are understood in the day-to-day thinking and practices of local government officials in England. Drawing on in-depth interviews with 85 individuals working on community cohesion policy, this perspective is refreshing in that it places the policy practitioner at the centre of analysis, rather than the more commonplace interest in formal policies and their outcomes. Jones (2013) emphasises the significance of considering feeling and emotion in how policy operates. This is especially pertinent in the case of local government officials, who find themselves in a position of governing but also being governed and in the process of this double positioning occupying emotionally uncomfortable positions, such as their often privileged position relative to those they are trying to help and of being acutely aware of but unable to address the challenges facing the communities that they serve. This research seeks to build on this work by not only examining the perceptions of local officials towards migrants, but also reflecting on how these representations go on to ultimately shape the local government policy practices.

The conceptual framework in this analysis, whilst inspired by the praiseworthy work of Alexander (2003) and Jones (2013), takes a slightly different stance from these authors. Rather than merely classifying local government attitudes towards the migrants or analysing the 'doing' of policy and government, the research also applies understandings in the migration literature of employer perceptions and representations of the 'good' (migrant) worker (Thompson et al, 2013) to policy practitioner understandings of the 'good' local migrant. This research emphasises the link between perceptions and practices in terms of how employers and recruiters engage with migrant labour. Akin to the contribution of Findlay et al (2013) the research goes beyond simply profiling how migrants are represented, by considering how these 
views connect to the actual making and implementation of policy at the local scale. The following two research questions emerge from the existent literature on this topic;

1. To what extent do local governments differ in terms of representations of and responses to immigration, and how can these be explained systematically?

2. How are migrants differentiated by local policy practitioners according to understandings of the good migrant and how do these perceptions ultimately relate to local policy responses?

\section{Local government and migration: policy landscape}

Whilst the rights and responsibilities of migrants is determined by national governments and even supranational institutions such as the European Union, it is local government that is ultimately responsible for providing services to migrants and ensuring their integration 'on the ground' (Kyambi, 2012; Rutter, 2013). National government has been surprisingly nonprescriptive in terms of specifying how local government should react to new arrivals from overseas (Saggar and Somerville, 2012). Many of the services that are provided by local authorities relate to so-called 'mandatory' requirements, meaning that they are required to provide certain services to residents due to legislation developed at central government level. In the UK context this includes the provision of general social, education and housing services and local economic development initiatives. Given their comparative economic disadvantage, this provision often impacts on immigrants to a greater extent than the population in general (Saggar and Somerville, 2012). 
As well as their mandatory requirements, local authorities also provide particular services and functions on a discretionary basis, meaning that they can choose to provide them but do not have to. With regards to migration such activities can include efforts to ensure that local employers, recruitment agencies and landlords comply with minimum legal standards, the promotion of migrant integration and steps to minimise community tensions (Audit Commission, 2007). It is common for local authorities to use their discretionary powers to undertake activities aimed at immigrants and issues relating to immigration (Byrne and Tankard, 2007), although this is becoming less prevalent given increasing budget constraints (Rutter, 2013).

Despite local authority services frequently being orientated towards issues concerning immigration, the myriad regulations regarding migrants' eligibility to local authority services (Kyambi, 2012), and ambiguity surrounding these rules, means that many local government officials are not fully aware of the extent to which they are required or permitted to support their immigrant populations (COSLA, 2011). For example in Scotland the local government representative group, the Convention Of Scottish Local Authorities (COSLA), has tried to summarise the key duties and powers available to local authorities in relation to immigrant groups (Kyambi, 2012). However even this attempt at clarity concedes that: 'Scottish Local Authorities have the power under section 20 of the Local Government of Scotland Act 'to promote wellbeing'. It is for local authorities in Scotland to consider whether to use these powers to provide support for immigrants excluded from other support. However, this is a power only and imposes no duty on local authorities' (Kyambi, 2012, 11). This lack of specificity could help to explain some of the diversity of responses to immigration that exist at the local government scale, given the often blurred distinctions between duties (services that must be provided), powers (services that may be provided at the discretion of individual local 
authorities) and exceptions whereby certain migrants are excluded from services according to their region of origin or immigration status.

\section{Methodological perspective}

The researchers engaged with local authority officials in Scotland to gauge their attitudes towards, and reactions to, immigration and immigrants. Taking place in the first eight months of 2014, the study involved in-depth interviews with half of all local authorities in Scotland. Our intention was to achieve a meaningful cross-section of Scotland's 32 local authorities, including urban and rural areas, regions with high concentrations of immigrants and local authorities experiencing only a limited level of immigration. Interviewees were mostly officials involved in Corporate Planning, Community Planning or Equalities. The interviews centred on three main themes: the process of planning services for migrants, identifying challenges/opportunities associated with migration and the future direction of these policies.

As Figure 1 illustrates, there is a particular geography of migrant settlement in Scotland. According to the most recent national census in 2011, many local authorities have only a small proportion of their residents who were born abroad whereas some urban areas have a non-UK born population of more than 15 per cent. The research was designed to engage with a range of local authorities according to their population size, location and experience of immigration. Potential interviewees were identified using online searches and were recruited through introductory emails followed up by telephone calls. Nearly all interviews occurred face-to-face, took place at the local authority's offices and typically lasted around an hour. All interviews were audio recorded, transcribed and analysed thematically using NVivo computer software. 
Figure 1 about here please

The research was conducted during the eight-month period leading up to the September 2014 referendum on Scottish independence from the UK. Although the proposition of independence was ultimately rejected by a majority of the electorate (55\%), this particular point in time was an especially expedient empirical lens through which local state perceptions of and responses to immigration could be analysed. The Scottish Government has long sought to encourage immigration, framing it as a key driver of economic and demographic growth. However control over immigration and borders is a responsibility that has remained 'reserved' to the UK government. At this scale, political sentiment is very different, with most policy and rhetoric aimed at reducing rather encouraging international immigration. These contrasting policy positions with regards to immigration have been the focus of much debate (Hepburn and Rosie, 2014). However these discussions have largely concentrated on the tensions between the conflicting 'national' policies of the Scottish and UK governments. Little attention has been paid to how local government within Scotland, or elsewhere for that matter, actually perceives, responds to and hence shapes immigration. The UK Government is largely responsible for 'national' immigration policy throughout Britain and whilst the Scottish government espouses a relatively liberal stance towards immigration, it is local government that must actually meet the potential challenges of immigration in terms of integration and the provision of housing, schooling, social care and other services. The limited existing evidence to date tentatively suggests that local governments in Scotland have in general been relatively pro-active in terms promoting migrant integration (Rutter, 2013). 


\section{Migration and the heterogeneity of local government}

Just as it is simplistic to represent the state as a single monolithic institution in migration studies, it is also important to emphasize that local authorities can have very diverse understandings of and therefore responses to immigration. However there has not yet been an attempt to systematically link perceptions of immigration to responses to it at this scale. Table 1 seeks to introduce a typology of local government responses to immigration that has some explanatory power in terms of illustrating how these responses vary and considering the factors which may explain these differences.

\section{Table 1 about here please}

As can be seen in Table 1, local governments were judged as responding to immigration in one of three ways; proactively, reactively or less actively. These groupings were based on the extent to which officials regarded their organisations as being 'active' in terms of how they planned for and responded to the issue of immigration. Key explanatory factors in this regard included: the level of migration in an area, the presence of individual local champions/activists and access to additional resources for exceeding statutory obligations. As such the extent to which local governments regarded themselves as 'active' with regards to immigration could be attributed to a combination of the urgency and/or scale of the challenge that they saw themselves facing in this respect and their eagerness and ability to engage with migrants in a more enduring and strategic manner. Each of the three categories in Table 1 is now discussed briefly in turn.

\section{Proactive Local Authorities}

These were usually areas with strong levels of economic and population growth but some labour and skills gaps. In some instances, proactive local authorities worked in collaboration 
with the private sector to recruit labour migrants from overseas. Council staff attended recruitment fairs overseas, promoting the area and supporting businesses seeking to attract an international workforce. Proactive local authorities also fostered links with Higher Education Institutions seeking to stimulate international student recruitment. Many of these councils also pursued partnerships with the voluntary sector and led regional and national networks focused on migration.

\section{$\underline{\text { Reactive Local Authorities }}$}

A third of the local authorities interviewed fitted into this category. Some had previously been much more active but had now adopted a more reactive position. Many of these interviewees described a frenzy of activity after the unforeseen arrival of large numbers of East-Central Europeans in the mid-2000s: research was commissioned, working groups established and migrant forums were energised. However migrant-focussed activity has receded for some of these councils: the volume of new migrants has stabilised after an initial surge, local policies are now in place to provide relevant services and central budgets have diminished. A number of interviewees emphasised the key role of enthusiastic individuals who act as local champions for migrant issues and have ensured they are kept 'on the agenda'. Some are elected members holding influential positions (e.g. Chair of an Equality Committee), others are officers with a personal interest in migration and others are community activists (often from within the migrant community) who agitate for greater focus on migrant issues. Individual personal commitment is paramount in these cases, but concerns were raised about succession and the sustainability of reliance on specific individuals to champion particular causes. 


\section{Less active Local Authorities}

A third of participating local authorities could be deemed 'less active'. Each fulfilled their statutory minimum requirements but for many, migration was simply not viewed as a priority. Most commonly these local authorities were in very rural regions and/or areas of economic and demographic decline and so do not experience much immigration. Interviewees from these locations were often vocal about the economic gains of in-migration but felt that unfavourable macro-economic forces conspired against their ability to retain or attract young and skilled workers. Less active local authorities therefore place little emphasis on specific 'migration issues', as a consequence of having few migrants and seeing little realistic prospect of notable inflows in the foreseeable future.

The classification system set out above is a simplification of experiences of and responses to migration at the local government scale in Scotland. Whilst areas receiving more migrants were generally more 'active' in their engagement with migration than those with smaller migrant communities, this does not necessarily imply a causal link between inflows and actions. It is already well established that differing policy responses are required according to the particular quantity and qualities of migrants that areas receive. The value of the typology therefore lies in the assertion that local governments and their officials are distinct in their exercise of agency towards migrants, and that being proactive as opposed to merely reactive matters in terms of the ability and propensity of places and populations to absorb migrants. As noted by Rutter (2013), the importance of individual leadership at the local government scale is an important determinant of the efforts and successes of efforts to promote migrant integration at the local scale. These actions, or inactions, hold significance since the dynamics of immigration policy 
and migrant integration largely play out at the local level rather than at the border of the nationstate.

\section{Local government and representations of the 'good' migrant}

As has been noted, analyses involving migration and policy have often considered 'the state' in a simplistic and unproblematic manner i.e. as an institution that is unitary and uniform (Favell, 2001). However as this research demonstrates, the reality is much more complex, with variations in representations and responses to immigration between local authorities being very significant. This is exemplified by the two contrasting perspectives cited below: first a local authority with no 'bespoke strategy' and second an example of a reactive policy initiated to avoid 'getting hit further down the line':

"We don't have a migration unit; if migrant families come and they want to put kids in school then the schools policies will take care of that. If they're community safety issues then Police will take care of that, and Community Safety Partnership colleagues in the Council. If there's issues of employment, Employability Services will take care of that. So we've never had a bespoke strategy to deal with migrants."

Martin, Corporate Policy, urban local authority

“We didn't expect all these Hungarians to come [from 2004], as they're entitled to under EU law, but we always adapt to these things... so it's not a statutory obligation to provide ESOL [English for Speakers of Other Languages] but we felt that we should provide it in order to prevent getting hit further down the line with issues with benefits and things"

Brian, Community Services, semi-rural local authority 
The differing approaches typified by these quotations are of interest, not only because of the contrast in local authority response, but also because they hint at the extent to which immigrants are perceived as being distinct from the population in general. The research uncovered evidence of local government officials differentiating and psychologically grading migrants in terms of their implications for service demands (Table 2). Officials largely represented the 'good' migrant (Scott, 2013) as being: of working age, in employment, with good language skills and unlikely to exert financial demands on the local authority through having children in schools, needing English language support or being in ill health. Accordingly more 'problematic' immigrants were framed as those lacking English language proficiency and families with dependents. Drawing on Alexander's (2003) local migrant policy framework and the local bureaucratic incorporation literature, Table 2 demonstrates how the attitudes of individual officials towards immigrants are significant in relation to their influence on specific local government policy practices.

\section{Table 2 about here please}

A prominent issue in terms of local perceptions of and responses to immigration which emerged was the extent to which immigrants are seen as being culturally alien or 'Other' to existing populations and whether particular groups might be at risk of 'losing out' in economic terms as a consequence of their presence. The concept of 'whiteness' has usefully been applied to the ways in which the racialization of white groups necessitates rethinking of widely held and longstanding assumptions about white power and privilege, which is usually juxtaposed against groups who are visibly different from the white dominant group (Ignatiev, 2009; Roediger, 2005). Social constructions of race and ethnicity are of value in understandings of recent immigration to Scotland, much of which has been 'white' in that it has involved significant inflows of immigrants from East-Central Europe, often to areas which have experienced little international immigration previously. Given that well over a million East- 
Central Europeans migrated to the UK over a short space of time, constituting the largest wave of immigration ever received by Britain (Bauere et al, 2007), most interviewees expressed the view that hostility to these recent immigrants has been remarkably muted. It has been suggested that this may be related to these immigrants being largely white and nominally Christian (Burrell, 2009). This is a view that was espoused by many of the local government officials that participated in the research.

“They [East-Central Europeans] are not coming from a third world country, they're westerners who have come here for jobs and who have the same lifestyles as us and the same thoughts and values... so there's never been a culture clash, whereas if there'd been large scale migration from other parts of the world then there would be more problems - issues about religion and belief systems and dress and all the rest of it".

Jeff, Equality and Diversity Manager, urban local authority.

Jeff's categorisation of East-Central Europeans as 'like us' speaks to the concept of whiteness, a broad analytical framework that has not yet been discussed in relation to this group of recent migrants. The perceived absence of significant cultural tensions between East-Central Europeans and the dominant group perhaps differentiates this wave of migration from some prominent historical examples of large scale 'white' immigration, such as Catholic immigrants to the US (Ignatiev, 2009), in that interviewees contended that most of the hostility felt towards East-Central Europeans derived from economic rather than cultural concerns. Despite studies of the fiscal impacts of immigration indicating little or no negative effect on native wage levels and employment opportunities (Docquier et al, 2014; Manacorda et al, 2012), the parts of the population who view themselves as 'losing out' to immigrants often find themselves in close residential proximity to new arrivals, causing potential for resentment (Alexander, 2003). This was a theme that was highlighted by some interviewees, who noted a stark dissonance between 
how immigration is perceived and represented by liberal minded professionals (including local authority officials and academics) and how it is understood by the resource poor, who regard themselves as in direct competition with immigrants for scarce employment opportunities and public services. The three quotations below chime with Jones's (2013) uncovering of the emotionally uncomfortable positions that local policy practitioners must negotiate in the course of their duties. In these cases officials professed tensions between the needs of migrants and the preferences of some existing residents.

"A Polish family moves in, absolutely legitimately, and then the rumours spread: 'a Polish family has jumped the queue again!'... so there's a disconnect between our professional, public policy environment which is largely middle class saying 'this is good for economic and ethnic diversity' and the reality of the citizen experience, which doesn't see that as the case".

Martin, Corporate Policy, urban local authority

An acceptance that some local residents felt an anxiety around immigration meant that interviewees emphasised the importance of sensitivity to potential tensions between economically disadvantaged groups and new immigrants when formulating strategies. For example one local authority decided not to participate in the UK-wide asylum dispersal policy because of concerns over how economically distressed parts of the existing community would respond.

"Asylum is a clear way of dramatically impacting on the diversity of your population, in a positive way. But you would be bringing a group of people who are already disadvantaged and already extremely vulnerable into a very volatile setting".

Owen, Community Services, urban local authority 
Whilst generally supportive of immigration as a positive phenomenon in cultural, demographic and economic terms, many local authority interviewees expressed concern that the ready supply of well perceived migrant workers enabled employers to extend 'flexible' working practices, which can ultimately be to the determent of low paid workers, migrant and non-migrant alike. Some interviewees thus expressed ambivalence about immigration, with a tension between the 'good' of economic and demographic growth and cultural diversity competing against the 'good' of social cohesion and opportunities for local economically disadvantaged residents.

"To continue growth then we need to attract more migrants in... but if you've got incoming workers that are easily available and who are perhaps more thankful for the opportunity than some of the local people then they might be easier employees... so employers might not invest in the youngsters. Part of my remit is also looking at youngsters as well, so I've got to be careful of the balance of opportunities".

Amanda, Economic Development, urban local authority.

\section{Discussion and conclusions}

This research has shed light on perceptions of, and responses to, migration at the local government level, a scale of analysis that is frequently overlooked in migration studies. Sitting within wider debates about the 'rescaling' of the role and sovereignty of the nation-state (Loboa et al, 2009; Hollifield, 2004), the article has sought to encourage an extension of North American scholarship on policy making and implementation at the local level to other geographic contexts. Rather than a consideration of the potential outcomes of local migration policies, the conceptual framework employed in this analysis draws inspiration from recent research which has emphasised the diversity of perceptions and responses to migration at the local government scale (Alexander, 2003; 2007), the ways in which local bureaucracies 
proactivity develop responses to migration within broader political and economic constraints (Lewis and Ramakrishnan, 2007; Marrow, 2007) and the significance of practitioner feeling and emotion in how policy operates (Jones, 2013). The methodological approach taken aimed to place local government officials at the centre of analysis, rather than the more prevalent scholarly interest in the impacts of migration policies.

The findings of this investigation can make a number of contributions to how migration policy making and implementation at the local scale is understood. The findings presented here echo Alexander's (2003) conviction that local authority attitudes towards (and thus responses to) migration is closely related to the extent of the perceived Otherness of their local immigrant population. Much of recent international migration to Scotland, especially to more rural new immigrant destinations, has been constituted by East-Central European migrants. These migrants were portrayed as not particularly 'different' to the existing population (they're Westerners who have the same lifestyles as us and the same thoughts and values, Jeff). Being a white and nominally Christian group, the alleged absence of Otherness on the part of these migrants meant that local officials did not see a particularly strong need for the development of initiatives to try and ensure their integration into their local communities. On the other hand more visibly 'different' migrants, such as asylum seekers, were regarded as presenting a greater challenge in community cohesion terms and thus these groups were perceived as needing more specific and tailored policy responses. These findings echo the host-stranger framework utilised by Alexander (2003), in that local government officials appear to favour 'non-policies' or 'guestworker' policies in some cases but assimilationist or pluralist responses in others. However whilst Alexander (2003) classifies these responses according to an evolution of local policies towards migrants over time, this analysis infers that differing stances can be better explained by assessments of the perceived Otherness of the migrants in question. 
Related to these ideas of migrants being differentiated by local government officials, this research points to policy practitioners drawing on cognitive 'virtual hierarchies of migrants' (Matthews and Ruhs, 2007, 17) when articulating their conceptions of the 'good' migrant. Just as these mental frameworks shape the practices of employers and recruiters by influencing who is recruited, from where and for what purposes (Findlay et al, 2013), they are also significant in the case of policy development and implementation at the local scale since these perceptions influence subsequent local government responses to migration (Table 2). Perceptions of the financial contribution or burden that different types of migrants make on local government was found to strongly influence the desirability of these groups and subsequent policy measures towards them.

In addition to the diversity of perceptions of particular types of migrant (Table 2), the research also uncovered a range of policy responses to migration between different areas (Table 1). These findings tie in with the emerging literature on local bureaucratic incorporation in the US, where local officials have been found to exercise a certain degree of autonomy in terms of how they interpret and implement national migration policies (Gleeson and Gonzales, 2011; Marrow, 2009). These points are significant because they contribute to the development of research on responses to migration 'on the ground' at the local government level, especially in the European context.

Whilst it is necessary to incorporate policy making and implementation at the sub-national level into migration studies (Leitner et al, 2002), it is important not to fetishize perceptions and practices at this scale of analysis (de Graauw, 2015). There are significant constraints on local state sovereignty in terms of influence on the migration system. Local government officials are 
able to exercise some discretion in terms of how they elect to respond to immigration, however these choices are made within a broader context in which it is national government which sets immigration legislation and the various other social and economic policies which have a major impact on local experiences of migration. Thus the local state predominantly operates within a policy framework dominated by central government and that it consequently has relatively little influence on. Furthermore, these local state actions are usually undertaken within constrained, and often shrinking, resource budgets. Lastly, the perceptions and practices of local government may have only limited influence over the attitudes and actions of other important actors in the migration system, such as employers, immigrants and existing populations, all of which will determine experiences of migration at the local scale.

A theoretical contribution offered by this investigation is that is encourages greater emphasis on the actual policy practitioner in policy research. This is of interest because conceptually it frames policymakers as reflexive self-conscious agents who simultaneously govern but are also governed (Jones, 2013). Such a perspective is to be welcomed since much migration policy research uncritically 'assumes that policy is something that is made in one place, enshrined in a document and implemented elsewhere' (Jones, 2013, 4). Evidence of practitioner emotion in how policy operates was evident in the discomfort of interviewees when they described how their liberal attitudes towards migration were at odds with the perceived views of many local residents, and how they experienced tension between a desire to help migrants find jobs, but also to improve the employment prospects of disadvantaged young local people. These points underline the importance of migration policy research, whether at the sub-national, national, or supranational scale, paying attention to the policymaker as well as to actual policies and their outcomes. Taken together, it is hoped that these contributions can help to address the relative 
neglect of the sub-national level in discussions concerning scales of governance in migration research.

Finally, by focusing on individual officials and the local level in migration policy making and implementation this research speaks to wider contentious issues regarding the policy relevance and applicability of scholarship in migration studies. A number of pertinent questions arise in this respect: given the many competing demands placed upon academics, to what extent should 'policy relevance' be prioritised? How can this best be achieved? And what are the potential pitfalls of such endeavours? Based on personal experience of working in both university and public policy settings, the author has noted several barriers to the effective translation of research into practice. Despite evermore emphasis on impact, as typified through pecuniary incentivisation in the Research Excellence Framework for example, academic excellence and positive influence on policy and public opinion are often perceived as mutually exclusive entities, with the latter treated with disdain by some within academia. These issues are particularly acute within the social sciences, where the nuance and often abstract nature of issues grappled with, and ongoing and vociferous nature of debates surrounding them makes it easier for policymakers to dismiss awkward or difficult research findings. On the other hand, policymakers are often guilty of exploiting favourable research to suit political agendas. For scholars, active engagement in 'impact' can thus risk compromising the integrity of their academic independence and result in doing 'applied' work that lacks intellectual satisfaction.

Going forward, it seems inescapable that social scientists will be expected to engage more actively with policy and policymakers. As outlined above, this is to be applauded to an extent since it is reasonable to assume that publicly funded research should contribute to improving 
society. Traditional research outlets and dissemination channels within academia are poorly suited to this task. The impact agenda can only help to increase the awareness of relevant research, aid communication of it and ultimately inform policy issues and public opinion for the better. However these laudable endeavours need to be carefully balanced against the need to protect and cherish the ultimate purpose of universities and core values of academia: the pursuit of human understanding, and recognition that this is rarely amenable to immediate or straightforward social or economic 'application' (Collini, 2012). Whilst not the core focus of this paper, many of the issues raised here speak to the need for a wider discussion within migration studies specifically and the social sciences more generally concerning the extent to which scholarly research agendas align with the priorities of policymakers, and the risks and rewards that such strategies entail.

\section{References}

Alexander, M. (2003). Local policies toward migrants as an expression of Host-Stranger relations: a proposed typology. Journal of Ethnic and Migration Studies, 29(3), 411-430.

Alexander, M. (2007). Cities and labour immigration: comparing policy responses in Amsterdam, Paris, Rome and Tel Aviv. Ashgate Publishing, Ltd.

Audit Commission (2007). Crossing borders: Responding to the local challenges of migrant workers. Audit Commission for Local Authorities and the National Health Service in England and Wales.

Bakewell, O. (2008). Research Beyond the Categories: The Importance of Policy Irrelevant Research into Forced Migration. Journal of Refugee Studies 21(4). Pp 432-453. 
Bauere, V. Densham, P. Millar, J. and Salt, J. (2007). 'Migrants from central and eastern Europe: Local geographies'. Population Trends, vol 129, pp. 7-19.

Bohn, S. Lofstrom, M. and Raphael, S. (2013). Did the 2007 Legal Arizona Workers Act Reduce the States Unauthorized Immigrant Population? Review of Economics and Statistics 96(2): 258-269.

Boswell, C. (2008). The political uses of expert knowledge: immigration policy and social research. Cambridge University Press. Cambridge.

Brenner, N. (2004). New state spaces. Urban governance and the rescaling of statehood. New York: Oxford University Press.

Burrell, K. (2009). 'Introduction: migration to the UK from Poland: continuity and change in East-West European mobility', in K.Burrell (ed) Polish Migration to the UK in the 'New' European Union: After 2004. Farnham: Ashgate. pp 1-19.

Byrne, J. Tankard, J. (2007). New European Migration: Good practice guide for local authorities. London: IDeA

Collini, S. (2012). What are Universities For? Penguin. London.

Convention of Scottish Local Authorities (2011) Strategic Migration Partnership: Policy toolkit v2.0. Edinburgh

De Graauw, E. (2015). Polyglot Bureaucracies: Non-profit Advocacy to Create Inclusive City Governments. Journal of Immigrant and Refugee Studies 13(2). pp 156-178

Docquier, F. Ozden, Ç. and Peri, G. (2014). The labour market effects of immigration and emigration in OECD countries. The Economic Journal, 124(579), 1106-1145. 
Favell, A. (2001). 'Integration policy and integration research: a review and critique', in Aleinikoff, A. and Klusmeyer, D. (eds) Citizenship: Global Perspectives and Practices. Washington DC: Brookings Institute/Carnegie Endowment, 249-299

Findlay, A. McCollum, D. Shubin, S. Apsite, E. and Krisjane, Z. (2013). 'The role of recruitment agencies in imagining and producing the 'good' migrant'. Social and Cultural Geography. 14(3). pp 145-163.

Gerber, E. and Kollman, K. (2004). Introduction-Authority Migration: Defining an Emerging Research Agenda. Political Science and Politics. 37(3). pp 397-401

Gleeson, S. and Gonzales, R. (2011). When Do Papers Matter? An Institutional Analysis of Undocumented Life in the United States. International Migration 50(4). pp 1-19.

Guiraudon, V. and Lahav, G. (2000). 'A reappraisal of the state sovereignty debate: the case of migration control'. Comparative Political Studies 33(2). pp 163-195.

Hepburn, E. and Rosie, M. (2014). 'Immigration, Nationalism and Political Parties in Scotland' in Hepburn, E., and Zapata-Barrero, R. (Eds.). The Politics of Immigration in Multi-level States: Governance and Political Parties. Palgrave Macmillan. 241-260

Hollifield, J. F. (2004). The Emerging Migration State. International Migration Review, 38(3), $885-912$.

Ignatiev, N. (2009). How the Irish became white. Routledge: Abingdon.

Iredale, R. Turpin, T. and Hawksley, C. (2004). Migration research and migration policy making: a study of Australia, the Philippines, and Thailand. International Social Science Journal 56(179). Pp 115-134. 
Jones, H. (2013). Negotiating cohesion, inequality and change: Uncomfortable positions in local government. Policy Press Scholarship Online: Oxford.

Jones, H. (2014). 'The best borough in the country for cohesion!' managing place and multicultural in local government. Ethnic and Racial Studies 37(4). pp 605-620.

Klebaner, B. (1958). State and Local Immigration Regulation in the United States before 1882. International Review of Social History 3(2). pp 269-295.

Kyambi, S. (2012) Establishing Migrants' Access to Benefits and Local Authority Services in Scotland. Convention of Scottish Local Authorities (COSLA)

Lacan, J. (2001) E' crits. London: Routledge

Laczko, F. and Wijkström, B. (2004). Enhancing the Contribution of Migration Research to Policy Making: Intergovernmental Workshop. International Migration 42(2). pp 175-183.

Leitner, H. Pavlik, C. and Sheppard, E. (2002). Networks, governance, and the politics of scale: Inter-urban networks and the European Union. In A. Herod M.W. Wright (eds.) Geographies of Power. Placing Scale. Oxford: Blackwell Publishers.

Lewis, P and Ramakrishnan, S. (2007). Police Practices in Immigrant-Destination Cities. Urban Affairs Review 42(6). pp 874-900

Lobao, L. Martin, R. Rodriguez-Pose, A. (2009). 'Editorial: Rescaling the state: new modes of institutional-territorial organization'. Cambridge Journal of Regions, Economy and Society 2(1). pp 1-10

Manacorda, M., Manning, A., and Wadsworth, J. (2012). The impact of immigration on the structure of wages: Theory and evidence from Britain. Journal of the European Economic Association, 10(1), 120-151. 
Marrow, H. (2009). Immigrant Bureaucratic Incorporation: The Dual Roles of Professional Missions and Government Policies. American Sociological Review 74. pp 756-776.

Massey, D. S. (1999). International migration at the dawn of the twenty-first century: The role of the state. Population and Development Review, 25(2), 303-322.

Matthews, G., and Ruhs, M. (2007). Are You Being Served? Employer Demand for Migrant Labour in the UK's Hospitality Sector. Centre on Migration, Policy and Society.

Pacquet, M. (2014). The Federalization of Immigration and Integration in Canada. Canadian Journal of Political Science 47(3). pp 519-548.

Poppleton, S., Hitchcock, K., Lymperopoulou, K., Simmons, J., and Gillespie, R. (2013). Social and public service impacts of international migration at the local level. Home Office, London.

Rodriguez, C. (2008). The Significance of the Local in Immigration Regulation. Michigan Law Review 106(4). pp. 567-642

Roediger, D. R. (2005). Working toward whiteness: How America's immigrants became white. Basic Books. New York.

Rutter, J. (2013). 'Back to basics, towards a successful and cost-effective integration policy'. Institute for Public Policy Research. London.

Saggar, S., and Somerville, W. (2012). Building a British model of integration in an era of immigration: policy lessons for government. Migration Policy Institute. Washington, DC.

Samers, M. (2001). "“Here to Work": Undocumented Immigration in the United States and Europe'. SAIS Review 21(1). pp 131-145. 
Scott, S. (2013). Migrant-local hiring queues in the UK Food industry. Population, Space and Place, 19(5), 459-471.

Thompson, P., Newsome, K., and Commander, J. (2013). 'Good when they want to be': migrant workers in the supermarket supply chain. Human Resource Management Journal, 23(2), 129-143.

Varsanyi, M. (2010).(ed). Taking Local Control: Immigration Policy Activism in U.S. Cities and States. Stanford University Press: Redwood City, CA.

Zolberg, A. R. (2006). A Nation by Design: Immigration Policy in the Fashioning of America. New York: Russell Sage Foundation.

Figure 1: Percentage of the population born outside the UK, 2011 census

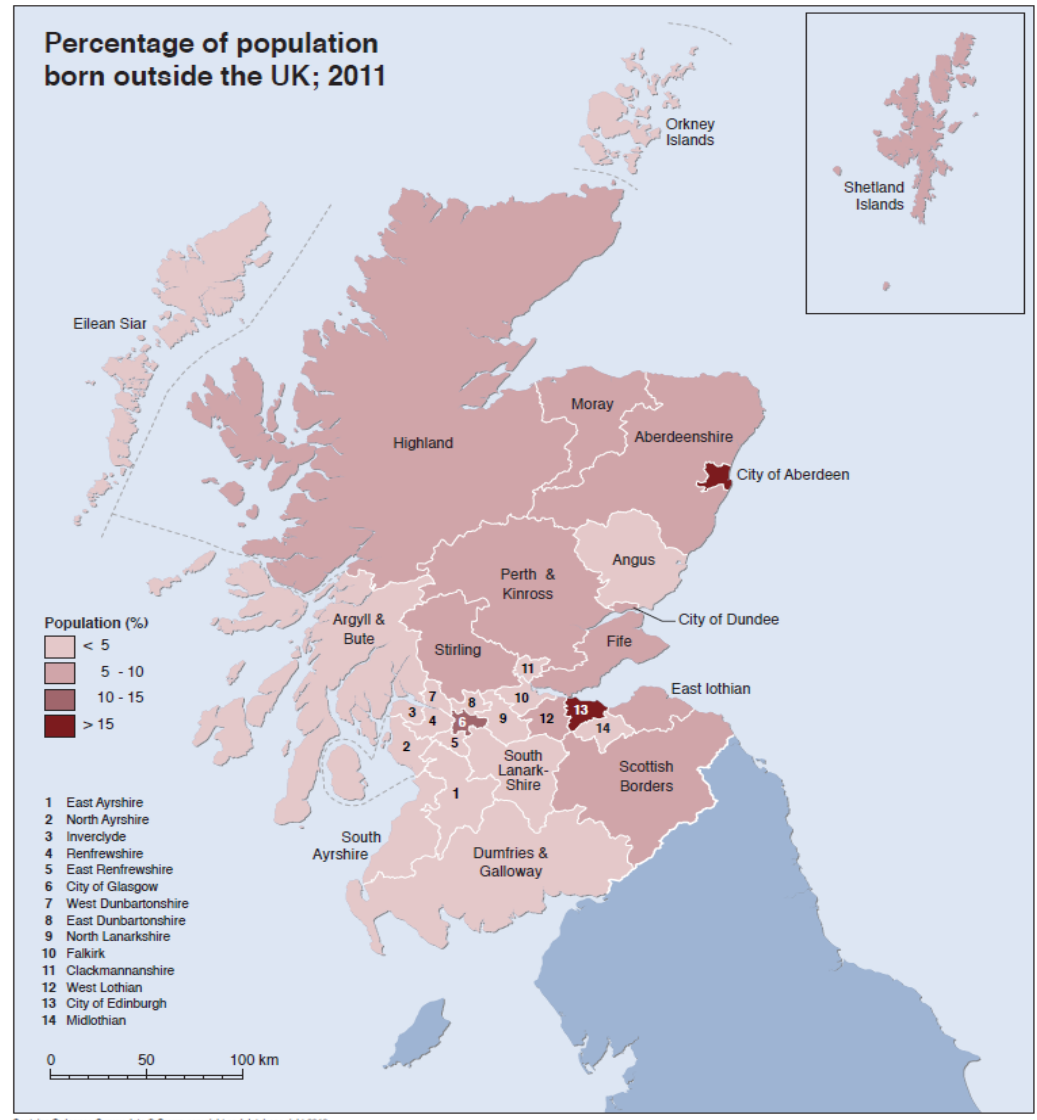

Source: Data from National Records of Scotland. Map produced by Graeme Sandeman 
Table 1: Diversity of local state experiences of and responses to immigration, a typology

\begin{tabular}{|l|l|l|l|}
\hline & Proactive response & Reactive response & Less active response \\
\hline Experience & $\begin{array}{l}\text { High immigration \& new } \\
\text { Traditional \& } \\
\text { immigration - urban } \\
\text { New immigration - semi- } \\
\text { urban \& rural }\end{array}$ & $\begin{array}{l}\text { Roderate immigration } \\
\text { new immigration } \\
\text { Semi-urban central regions } \\
\text { experiencing growth in size } \\
\text { of their migrant communities }\end{array}$ & $\begin{array}{l}\text { Low immigration } \\
\text { Economically } \\
\text { remogions } \\
\text { Sparsely populated regions }\end{array}$ \\
\hline Discourse & $\begin{array}{l}\text { "We do see migration is very } \\
\text { relevant to us. Any } \\
\text { approaches to migration, any } \\
\text { work around that: we need to } \\
\text { beat the table! We're an area } \\
\text { that is affected by it!" }\end{array}$ & $\begin{array}{l}\text { just don't plan because we } \\
\text { had planned for the deluge } \\
\text { and it just didn't happen?" }\end{array}$ & $\begin{array}{l}\text { "But let's face I don't think } \\
\text { migration is key! It's not the } \\
\text { foremost of our thoughts, } \\
\text { given the public sector } \\
\text { funding restraints" }\end{array}$ \\
\hline $\begin{array}{l}\text { Reaction } \\
\text { labour migrants from } \\
\text { abroad } \\
\text { Taking a lead role in } \\
\text { national/regional migrant } \\
\text { issues } \\
\text { Migrants viewed as active } \\
\text { citizens contributing to the } \\
\text { local area (economically and } \\
\text { demographically) }\end{array}$ & $\begin{array}{l}\text { Ad hoc involvement in } \\
\text { cross-sector working groups } \\
\text { on migrant issues. } \\
\text { Migrant forums maintained } \\
\text { by 'local champions' } \\
\text { (officers, elected members) } \\
\text { Migrants viewed as } \\
\text { 'different' i.e. residents with } \\
\text { particular needs }\end{array}$ & $\begin{array}{l}\text { Limited awareness of } \\
\text { migrant issues/networks } \\
\text { Scarce resources for ESOL } \\
\text { classes/translation and } \\
\text { interpretation. } \\
\text { Migrant issues are said to be } \\
\text { "incorporated in Community } \\
\text { Planning structures" }\end{array}$ \\
\hline
\end{tabular}


Table 2: Perceptions of the good migrant and subsequent policy practices

\begin{tabular}{|c|c|c|}
\hline $\begin{array}{l}\text { Category of } \\
\text { migrant }\end{array}$ & Signifier & Signified, and resulting practice \\
\hline $\begin{array}{l}\text { Young transitory } \\
\text { migrants }\end{array}$ & $\begin{array}{l}\text { We get a lot of young migrants who come and go, } \\
\text { very much transitory, and who work in the service } \\
\text { industry, which is good because that is where we } \\
\text { continue to struggle in terms of labour supply } \\
\text { (Urban LA) }\end{array}$ & $\begin{array}{l}\text { Boosts labour supply } \\
\text { Few resource implications. } \\
\text { No specific measures needed }\end{array}$ \\
\hline Foreign students & $\begin{array}{l}\text { There are big universities here, and foreign students } \\
\text { arrive who are very affluent... so they often don't } \\
\text { need our support } \\
\text { (Urban LA) }\end{array}$ & $\begin{array}{l}\text { Contributors to local economy } \\
\text { Few resource implications. } \\
\text { No specific measures needed }\end{array}$ \\
\hline $\begin{array}{l}\text { The habitual } \\
\text { seasonal migrant }\end{array}$ & $\begin{array}{l}\text { You have the people who work in agriculture, they } \\
\text { come in summer and go back to Poland again or } \\
\text { wherever and have been doing that for years and } \\
\text { they're getting on with it and they're not bothering } \\
\text { us. So great! That's basically the attitude. So until } \\
\text { something comes and hits us in the face we're not } \\
\text { going to go looking for it." } \\
\text { (Semi-rural LA) }\end{array}$ & $\begin{array}{l}\text { Seasonal contributors to local } \\
\text { economy. } \\
\text { Few resource implications } \\
\text { No forward planning, ad hoc } \\
\text { measures only }\end{array}$ \\
\hline $\begin{array}{l}\text { The lone labour } \\
\text { migrant }\end{array}$ & $\begin{array}{l}\text { They come in, they tend to be working, they tend not } \\
\text { to have a great demand on council services initially } \\
\text { because a lot of them are single, don't have children } \\
\text { at school and rarely any social issues either } \\
\text { (Urban LA) }\end{array}$ & $\begin{array}{l}\text { Purely labour migrants: economic } \\
\text { contribution } \\
\text { Few resource implications } \\
\text { Some efforts to ensure aware of } \\
\text { employment rights }\end{array}$ \\
\hline $\begin{array}{l}\text { Hard working } \\
\text { families }\end{array}$ & $\begin{array}{l}\text { Last year for the first time we had families working } \\
\text { on the farms. Not young children but the mum and } \\
\text { dad and teenage children were all over } \\
\text { (Rural LA) }\end{array}$ & $\begin{array}{l}\text { Labour migrants: mainly positive } \\
\text { net economic contribution } \\
\text { Impact on schools } \\
\text { Usually sufficient English } \\
\text { language skills }\end{array}$ \\
\hline $\begin{array}{l}\text { Extended } \\
\text { families }\end{array}$ & $\begin{array}{l}\text { The networks are here so now we're getting whole } \\
\text { family units into our area; mothers, grannies, } \\
\text { children and uncles. } \\
\text { (Semi-rural LA) }\end{array}$ & $\begin{array}{l}\text { Positive impact of labour migrants } \\
\text { negated by presence of dependents } \\
\text { Pressure on schools } \\
\text { Pressure on English language } \\
\text { provision } \\
\text { Pressure on healthcare and services } \\
\text { for older people }\end{array}$ \\
\hline $\begin{array}{l}\text { The problematic } \\
\text { migrant }\end{array}$ & $\begin{array}{l}\text { We have noticed an increase in migrants claiming } \\
\text { benefits because they've been here long enough to } \\
\text { earn that right. They're problematic because they're } \\
\text { not able to get employment or an improved level of } \\
\text { employment because of their lack of English skills. } \\
\text { (Urban LA) }\end{array}$ & $\begin{array}{l}\text { Fiscal burden } \\
\text { Poor English } \\
\text { Lack employability skills } \\
\text { Demands on welfare and } \\
\text { translation services } \\
\text { Other social problems e.g. } \\
\text { alcoholism, homelessness }\end{array}$ \\
\hline
\end{tabular}

